\title{
Farmer field school's training on knowledge level of citrus growers regarding improved production practices
}

\author{
Akash Nougha Victor ${ }^{1}$ Muhammad Luqman $^{1 *}$ Xu Shiwei ${ }^{2}$ \\ Yu Wen ${ }^{2}$ Muhammad Zeeshan Majeed $^{1}$
}

${ }^{1}$ Department of Agri. Extension \& Rural Development, University College of Agriculture, University of Sargodha, Pakistan.

${ }^{2}$ Agricultural Information Institute (AII), Chinese Academy of Agricultural Sciences, Beijing, China. E-mail: muhammadluqman_uos@yahoomail.com. ${ }^{*}$ Corresponding author.

\begin{abstract}
The major objective of this paper was to assess the impact of the Farmer field school (FFS) training program on the knowledge level of farmers (citrus growers) regarding improved citrus production practices. Distract Sargodha was the targeted research area for this study being the leading producer of citrus in Pakistan. Quantitative data were collected through interview schedule and analyzed through Statistical Package for Social Sciences (SPSS). It was conclude that young people were more tend towards getting training under FFS program than old age farmers. Educated farmers were in majority in FFS farmers while; conversely illiterate farmers were in majority in the category of non-FFs farmers. In category of FFS farmers livestock farming was their primary income as reported by majority (31.3\%) of FFS farmers and in the case of non-FFS farmer's crop sale was their primary income source as reported by $28.4 \%$ of non-FFs farmers. In addition to that both FFS and non-FFS farmers also earn income from nonfarm sources like business, job, foreign remittances and labour. FFS training program had positive and significant impact on the knowledge level of farmers regarding citrus production and protection practices. T-test statistics showed highly significant $(P<0.05)$ difference in knowledge level of FFS farmers and non-FFS farmers.

Key words: farmer field school, agricultural extension, integrated pest management, citrus production practices.
\end{abstract}

Impacto do treinamento da escola de campo para agricultores quanto ao nível de conhecimento dos produtores de citros em relação às melhores práticas de produção

RESUMO: O objetivo principal deste trabalho foi avaliar o impacto do programa de treinamento da escola de campo para agricultores (FFS) quanto ao nível de conhecimento dos agricultores (produtores de citros) em relação às melhores práticas de produção de citros. O Distrito de Sargodha foi a área de pesquisa escolhida para este estudo por ser o principal produtor de citros no Paquistão. Os dados quantitativos foram coletados por meio de entrevistas e analisados por meio do Statistical Package for Social Sciences (SPSS). Conclui-se que os jovens eram mais tendenciosos à obtenção de treinamento através do programa FFS do que os agricultores mais velhos. Os agricultores escolarizados estavam, em sua maioria, na categoria de agricultores FFS, enquanto que os agricultores analfabetos estavam, na categoria de não FF. Na categoria de FFS, a pecuária se mostrou o principal rendimento, conforme relatado pela maioria dos agricultores (31,3\%), enquanto que, em $28 \%$ dos agricultores não-FFs, a principal fonte de renda era a venda de suas colheitas. Além disso, tanto os agricultores FFS como não FFS também ganham renda com fontes não agricolas. O programa de treinamento FFS teve impacto positivo e significativo sobre o nivel de conhecimento dos agricultores em relação às práticas de produção e proteção de citrus. O teste-T mostrou diferença altamente significativa $(P<0,05)$ no nível de conhecimento dos agricultores FFS dos não-FFS.

Palavras-chave: escola de campo para agricultores, extensão agrícola, manejo integrado de pragas, práticas de produção de citros.

\section{INTRODUCTION}

Pakistan is also included in the list of those countries where nearly half of the population residing in rural areas whose livelihoods depends on agriculture. This is the single largest sector of economy and contributes $19.8 \%$ to national GDP. Fruits are the main sub-sector of crop production having significant share in overall agriculture (GOVERNMENT OF PAKISTAN, 2016). A lot of foreign exchange comes from export of fruits every year especially in low income and developing countries (LANJOUW \& LANJOUW, 2001). Other than the economic importance of fruits, they are an important element of human diet and main source of energy (PERKINS-VEAZIE \& COLLINS, 2001).

The climate of Pakistan is very much conducive in producing variety of fruits. A number of fruits are widely grown in all the provinces of country. But the share of Punjab province in producing high 
quality fruits is highest (BALOCH et al., 2006). Among different fruits citrus is widely grown on large scale. The share of the Punjab province in producing Citrus is 95.0\% (GOVERNMENT OF PAKISTAN, 2006). Research studies proved that development of rural people is dependent of development of agriculture sector. For effective and efficient agricultural management system, it is necessary that extension services must deal with the problems of farmers (LODHI et al., 2006). Agricultural extension or rural advisory services in developing countries have been changing in the last decade. In new paradigms of development, emphasis was on participatory learning for capacity building of farmers and their sustainable empowerment (ALI et al., 2011). Farmer field schools (FFS) was the typical example of such agricultural extension techniques in which participatory learning techniques were used to educate the farmers regarding crop management practices (VAN DEN BERG, \& JIGGINS, 2007).

In Pakistan as well, agricultural extension services which are the responsibility of provinces is highly criticized during the last three decades due to weak linkages with all the potential and major stakeholders (LUQMAN et al., 2005). In this critical situation and age of modern change during late 1990s, there was dire need to bring changes in the extension strategies from top down to participatory. FFS participatory learning approach was also introduced in Pakistan after viewing its positive impacts on agricultural productivity and also helps in increasing farmer's knowledge (WINARTO, 2004; TRIPP et al., 2005; BENTLEY et al., 2007). In Pakistan FFS was initially introduced in cotton crop (BUTT et al., 2015). In view of its impacts on farmer knowledge, Government of the Punjab adopted FFS methodology in 2005 to train the fruit and vegetable growers in the province. The program was started in 12 different Implementation Units including Sargodha being the leading producer of citrus. In this project training was given to citrus growers regarding citrus management practices. With this basic idea, the purpose of current research study was to check the impact of FFS training program on knowledge level of citrus growers regarding improved citrus production practices in Sargodha district.

\section{MATERIALS AND METHODS}

\section{Target area}

The study was conducted in District Sargodha, which was located in central part of the Punjab province and serve as targeted area of the study. The district is very much famous due to leading producer and exporter regarding quality citrus throughout the world. Survey research design was used in the present research. Due to the different nature of study, two types of sampling procedures (purposive and simple random) were adopted for the selection of targeted respondents. The district is divided into six sub districts (Sargodha, Silanwali, Kot Momin, Bhalwal, Shah Pur, and Sahiwal). Out of these, two districts, Sargodha and Bhalwal were selected purposively having highest population. All the villages of these two selected districts where FFS training program was implemented served as population for the study. The population was divided into two categories:

\section{Category I: Treatment group}

This group comprises of those farmers (citrus growers), who got training under FFS program of Fruit and Vegetable Development project of Punjab government.

\section{Category II: Control group}

This group comprises of those farmers (citrus growers), who were the residents of that same village as that of treatment group but didn't attended FFS training program.

\section{Research design}

Experimental survey research design was used as the population was divided into two categories (treatment group and control group) to check the impact of FFS training program on the knowledge level of citrus growers.

\section{Sampling technique}

Different sampling techniques are being used while conducting social science research studies. Keeping in mind the objectives and nature of the study, purposive sampling (Non probability) and simple random sampling (Probability) were used for the selection of targeted subjects of the current research study. Total sample size of this research study was 320 citrus growers (160 FFS farmers and 160 Non-FFS farmers).

\section{Data collection and analysis}

Quantitative data were collected by using structured interview schedule as research instrument. Five point likert scale was used to assess the knowledge level of two categories of respondents (FFS and Non-FFS farmer). The collected data were analyzed through SPSS for tabulation and 
interpretation using descriptive and inferential statistics. In order to compare the knowledge level of both the two categories of respondents (to check the impact of FFS training on knowledge level of citrus growers), paired t-test was applied.

\section{RESULTS AND DISCUSSION}

\section{Socio-economic attributes}

In social science research studies socioeconomic attributes of respondents play a significant role. In the present research study, data regarding some socio-economic attributes of respondents (age, educational level, and farm size) were collected and presented in table 1 .

The data regarding age of the respondents shows that in category of FFS respondents, the age of majority of the FFS farmers (slightly more than half) was 18-35 years. But opposite situation was reported in case of non-FS farmers, where the age of majority of the non FFS farmers (53.8\%) was 36-50 years. This showed that young farmers having lower age were more inclined to get training related to new innovations in agriculture compared to farmers with higher age. The tendency of young farmers to adopt new agricultural technology and getting access to new agricultural innovations was more than old age farmers. In relation to these results NMADU et al. (2015) also reported that young farmers were more receptive to adopt agricultural innovations than older ones. The data regarding age of the respondents also indicate that there is significant difference in age of FFS farmers and non-FFS farmers. The involvement of young age group in FFS training program in the Punjab Pakistan was also reported by IRSHAD et al. (2016).

The data related to educational status of respondents showed that in category of FFS farmers, the majority of respondents had secondary level education (up to ten years of schooling). Conversely, entirely opposite results was reported in case of educational status of non FFS farmers where majority were illiterate (non-formal education). This indicated that educated farmers were more inclined towards getting training through FFS than uneducated ones. The reason behind this is that the philosophy of FFS is based on education, learning through experience involving activities which are best performed by people having education than illiterates. Similar results were also quoted by MUHAMMD et al. (2015). They concluded that majority of the FFS farmers were literate.

The data regarding farm size of respondents as given in table 1 showed that in the category of FFS citrus growers $50.0 \%$ had $11-20$ acres of agricultural land followed by $31.3 \%, 11.3 \%, 5.0 \%$ and $2.5 \%$ who had 21-30 acres, more than 40 acres, upto 10 acres and 31-40 acres of agricultural land, respectively. Conversely in the category of non-FFS citrus growers, high majority of $(87.5 \%)$ had agricultural land upto ten (10) acres. Ten per cent of them had 11-20 acres of land and only $2.5 \%$ had $31-40$ acres of land. This showed that in non-FFS citrus growers,

Table 1 - Socio-economic attributes.

\begin{tabular}{|c|c|c|c|c|}
\hline \multirow{2}{*}{ Age } & \multicolumn{2}{|c|}{---------------------FFS farmers----------------- } & \multicolumn{2}{|c|}{------------Non-FFS farmers----------. } \\
\hline & $\mathrm{F}$ & $\%$ & $\mathrm{~F}$ & $\%$ \\
\hline Young age group (18-35 Years) & 83 & 51.9 & 36 & 22.5 \\
\hline Middle age group (36-50 Years) & 55 & 34.4 & 86 & 53.8 \\
\hline Old age group (More than 50 years) & 22 & 13.7 & 38 & 23.8 \\
\hline \multicolumn{5}{|c|}{ 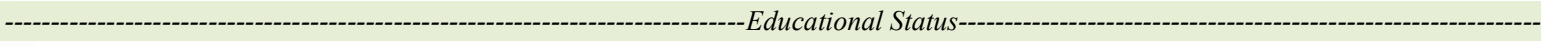 } \\
\hline Illiterate & 10 & 6.2 & 54 & 33.8 \\
\hline Primary & 22 & 13.8 & 34 & 21.3 \\
\hline Middle & 32 & 20.0 & 20 & 12.5 \\
\hline Secondary (Matriculation) & 44 & 27.5 & 08 & 5.0 \\
\hline Intermediate & 12 & 7.5 & 20 & 12.5 \\
\hline Graduation and above & 40 & 25.0 & 24 & 15.0 \\
\hline \multicolumn{5}{|c|}{ - } \\
\hline Upto 10 Acres & 8 & 5.0 & 140 & 87.5 \\
\hline 11-20 Acres & 80 & 50.0 & 16 & 10.0 \\
\hline 21-30 Acres & 50 & 31.3 & 0 & 0.0 \\
\hline 31-40 Acres & 04 & 2.5 & 04 & 2.5 \\
\hline More than 40 acres & 18 & 11.3 & 0 & 0.0 \\
\hline
\end{tabular}


small land holding is most common compared to FFS farmers where majority of the farmers had 11-30 acres of agricultural land. The data also indicated that large land holders were more interested to get new agricultural technologies and innovations related to agriculture like participation in FFS training program as compared to small land holders, who used to do subsistence farming with limited financial and physical resources.

\section{Income sources}

In rural areas people earn income from diversified nature of sources (both farming and nonfarming). For better income both farming and nonfarming income sources are very much necessary. Diversification of income sources lowers the vulnerability of farmers from external environmental threats and economic shocks. In this research income sources of respondents were divided into three categories as primary, secondary and tertiary. The data regarding these income sources of FFS farmers and non-FFS farmers is given in table 2 .

The data presented in table 2 regarding income sources of FFS farmers showed that their primary income sources were livestock farming, foreign remittances, salary/pension, business, crop sale and labor as reported by $31.3 \%, 28.8 \%, 16.3 \%, 10.0 \%$, $10.0 \%$ and $3.8 \%$, respectively. This indicated that FFS famers mostly used to earn income from livestock farming as they perceived that livestock farming is more profitable business than crop cultivation. Majority of FFS farmers said that livestock gives better income returns than crop sale. The secondary income sources of FFS farmers were crop sale, livestock farming, business, salary/pension and foreign remittances as responded by $51.3 \%, 23.8 \%, 21.3 \%, 2.5 \%$ and $1.3 \%$ respectively. Tertiary income sources of FFS citrus growers were crop sale, business, livestock farming and salary/pension as reported by $46.3 \%, 40.0 \%, 8.7 \%$ and $5.0 \%$, respectively. This showed that FFS farmers earn income form farming as well as non-farming income sources. In farming income sources crop sale and livestock farming were the major sources. Conversely, in non-farming income sources business, foreign remittances, salary/pension and labor were the major ones. The major livelihood activity for FFS farmers in the research area was farming (crop sale and livestock farming). The data also indicated that FFS farmers adopt crop sale as secondary and tertiary income sources. Their major concern is on livestock farming as livestock is one of the emerging profitable economic activities in rural areas of Pakistan (ABEDULLAH et al., 2009).

Conversely, different results were found regarding income sources of non-FFS farmers as given in table 2 . The data given showed that primary income source of non-FFS farmers were crop sale, livestock farming, business, salary/pension, foreign remittances, and labor as reported by $28.4 \%, 26.4 \%$, $16.3 \%, 13.8 \%, 13.8 \%$ and $1.3 \%$, respectively. This showed that in opposite to FFS farmers, major income source of non-FFS farmers was crop sale instead of livestock farming with small percentage of difference between both of these primary income sources. The data further indicated that more than $50 \%$ of non-FFS farmers $(54.8 \%)$ used to get income from farming activities and depend upon farm economy. But $45.2 \%$ of non-FFS farmers adopt nonfarm income sources to get income for livelihoods. This is clear from the findings that non-farmers rely more on farm economy than on-farm economy. The secondary income sources of non-FFS farmers was livestock farming, crop sale, business, salary/pension and labour as stated by $38.8 \%, 28.4 \%, 17.6 \%, 8.9 \%, 5.0 \%$ and $1.3 \%$, respectively. Tertiary income sources of non-FFS farmers was crop sale, business, livestock farming, salary/pension and labor as responded by $38.8 \%$, $25.0 \%, 20.0 \%, 15.0 \%$ and $1.3 \%$, respectively. This

Table 2 - Primary, secondary and tertiary income sources of FFS and Non-FFS farmers.

\begin{tabular}{|c|c|c|c|c|c|c|c|c|c|c|c|c|}
\hline \multirow{3}{*}{$\begin{array}{l}\text { Farmer's category } \\
\text { Income sources }\end{array}$} & \multicolumn{6}{|c|}{ 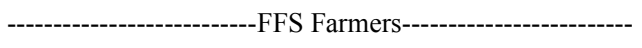 } & \multicolumn{6}{|c|}{ 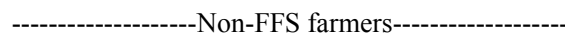 } \\
\hline & \multicolumn{2}{|c|}{-----Primary----- } & \multicolumn{2}{|c|}{---Secondary--- } & \multicolumn{2}{|c|}{----Tertiary---- } & \multicolumn{2}{|c|}{---Primary--- } & \multicolumn{2}{|c|}{--Secondary- } & \multicolumn{2}{|c|}{----Tertiary---- } \\
\hline & $\mathrm{F}$ & $\%$ & $\mathrm{~F}$ & $\%$ & $\mathrm{~F}$ & $\%$ & $\%$ & $\mathrm{~F}$ & $\%$ & $\%$ & $\mathrm{~F}$ & $\%$ \\
\hline Crop sale & 16 & 10.0 & 82 & 51.3 & 74 & 46.3 & 46 & 28.4 & 46 & 28.4 & 62 & 38.7 \\
\hline Business & 16 & 10.0 & 34 & 21.3 & 64 & 40.0 & 26 & 16.3 & 28 & 17.6 & 40 & 25.0 \\
\hline Livestock farming & 50 & 31.3 & 38 & 23.8 & 14 & 8.7 & 42 & 26.4 & 62 & 38.8 & 32 & 20.0 \\
\hline Salary/pension & 26 & 16.3 & 4 & 2.5 & 08 & 5.0 & 22 & 13.8 & 14 & 8.9 & 24 & 15.0 \\
\hline Foreign remittances & 46 & 28.8 & 2 & 1.3 & 0 & 0.0 & 22 & 13.8 & 08 & 5.0 & 0 & 0.0 \\
\hline Labour & 06 & 3.8 & 0 & 0.0 & 0 & 0.0 & 02 & 1.3 & 02 & 1.3 & 02 & 1.3 \\
\hline
\end{tabular}


indicated that in all the cases non-FFS farmers get income from crop sale compared to livestock farming and other non-farm economic sources. This indicated that FFS farmers adopt crop production practices as side business and non-FFS farmers mostly get major income from crop production practices.

\section{Impact of FFs training on knowledge level of farmers}

The major objective of the current study was to assess the impact of FFS training program on the knowledge level of citrus growers. The existing knowledge level of both the categories of respondents was determined through five point likert scale. Improved citrus management practices were divided into two parts, one deal with production side and other deal with protection practice. Mean, SD and value of t-test statistics regarding different citrus production and protection practices were calculated through SPSS. The data in this regard in given in table 3.

The data given in table 3 showed that in all the production related practices of citrus, the mean value of FFS farmers was higher than nonFFS farmers. In all practices, the mean difference regarding knowledge level of FFS farmers and nonFFS farmers showed positive value. This indicated that the knowledge level regarding citrus production practices of citrus growers who get training under FFS program was higher compared to the knowledge level of non-FFS farmers. This showed that FFS training program had positive impact on the knowledge level of farmers. This program played important role in upgrading farmer's knowledge. The overall mean value regarding knowledge level of FFS farmers about citrus production practices $(3.64 / 5.00)$ was higher than non-FFS farmers (2.74/5.00).

Some extent different results were found in case of knowledge level of FFS farmers and non-FFS farmers about citrus protection practices and management. The knowledge level of FFS farmers was high in case of majority of the citrus protection practices like regular pest scouting (Mean difference $=1.19$ ), mechanical control measures $($ Mean difference $=1.31$ ), biological control measures (Mean difference $=1.88$ ) and field sanitation (Mean difference $=0.39$ ). This indicated that in these citrus protection practices FFS training program played significant role in improving their knowledge level especially in case of biological control measures, whose mean difference was highest among others. This proved that FFS program play important role in controlling the insects/pests of citrus through biological control instead of chemical control. The philosophy of FFS training program was also based on IPM practices, in which major focus was given on application biological control measures as reported by MANCINI et al. (2008). In two

Table 3 - Comparison of knowledge level of FFS \& Non-FFS farmers regarding citrus production practices.

\begin{tabular}{|c|c|c|c|c|c|c|}
\hline \multirow{2}{*}{ Knowledge level regarding } & \multicolumn{2}{|c|}{-------FFS farmers------ } & \multicolumn{2}{|c|}{---Non-FFS farmers--- } & \multirow{2}{*}{ Mean difference } & \multirow{2}{*}{ t-test } \\
\hline & Mean & SD & Mean & SD & & \\
\hline \multicolumn{7}{|c|}{ Production practices----- } \\
\hline Nursery management & 4.03 & 0.816 & 3.36 & 0.834 & 0.67 & $7.011^{* * *}$ \\
\hline Propagation techniques & 4.04 & 0.823 & 3.34 & 0.784 & 0.70 & $7.368^{* * *}$ \\
\hline Soil management & 3.79 & 0.898 & 3.59 & 0.722 & 0.20 & $2.373^{* *}$ \\
\hline Pruning & 3.92 & 0.931 & 3.56 & 0.866 & 0.36 & $3.647^{* * *}$ \\
\hline Irrigation management & 4.17 & 0.818 & 4.04 & 1.089 & 0.13 & $1.272^{\mathrm{NS}}$ \\
\hline Application of farm yard manure & 3.27 & 0.791 & 2.23 & 1.233 & 1.04 & $9.100^{* * *}$ \\
\hline Application of balanced fertilizer & 3.31 & 0.832 & 1.64 & 0.886 & 1.67 & $16.983^{* * *}$ \\
\hline Application of micro-nutrients & 3.27 & 0.895 & 1.42 & 0.835 & 1.85 & $19.191^{* * *}$ \\
\hline Post-harvest handling and packing & 2.96 & 1.005 & 1.46 & 0.889 & 1.50 & $12.759^{* * *}$ \\
\hline Overall mean & 3.64 & 0.868 & 2.74 & 0.904 & & \\
\hline \multicolumn{7}{|c|}{----1-} \\
\hline Regular pest scouting & 3.02 & 0.894 & 1.83 & 0.826 & 1.19 & $-12.430^{* * *}$ \\
\hline Chemical control measures & 3.27 & 0.758 & 4.45 & 0.923 & -1.18 & $8.966^{* * *}$ \\
\hline Mechanical control measures & 3.33 & 0.880 & 2.02 & 1.580 & 1.31 & $-6.974^{* * *}$ \\
\hline Biological control measures & 4.23 & 0.921 & 2.35 & 0.946 & 1.88 & $18.744^{* * *}$ \\
\hline Cultural control measures & 3.69 & 0.746 & 3.80 & 0.917 & -0.11 & $3.790^{* * *}$ \\
\hline Field Sanitation & 3.42 & 0.865 & 3.03 & 0.980 & 0.39 & $13.251^{* * *}$ \\
\hline Overall mean & 3.49 & 0.844 & 2.913 & 1.029 & & \\
\hline
\end{tabular}

${ }^{* * *}=$ Highly significant, ${ }^{* *}=$ Significant NS $=$ Non-Significant (Scale: $1=$ V. Low, $2=$ Low, $3=$ Medium, 4= High, 5= V. High). 
citrus protection practices, the mean value regarding knowledge level of non-FFS farmers was higher than FFS farmers like chemical (Mean difference $=-1.18$ ) and cultural control measures (Mean difference $=-0.11$ ). In these practices, the negative value showed that FFS training program had no impact on the knowledge of farmers about the application of chemical and cultural control measures against citrus insect/pest and diseases. The positive impact of FFS on the knowledge level of farmers was also explained by IRSHAD et al. (2016).

The value of t-test and significance level of different citrus production and protection practices showed that in all the citrus production and protection practices, highly significant $(\mathrm{P}<0.05)$ difference was reported regarding knowledge level of FFS farmers and non FFS farmers. In one aspect of citrus production practices "irrigation management" non-significant difference was reported. This showed that FFS training program significantly improved the knowledge of farmers with regard to improved citrus production and protection practices.

\section{CONCLUSION}

It was concluded that young people were tend towards getting training under FFS program than old age farmers. Educated farmers were in majority in FFS farmers while on the other hand illiterate farmers were in majority in the category of non-FFs farmers. In category of FFS farmers livestock farming was their primary income as reported by majority (31.3\%) of FFS farmers and in the case of non-FFS farmer's crop sale was their primary income source as reported by $28.4 \%$ of non-FFs farmers. In addition to that both FFS and non-FFS farmers also earn income from nonfarm sources like. FFS training program had positive and significant impact on the knowledge level of farmers regarding citrus production and protection practices. T-test statistics showed highly significant $(\mathrm{P}<0.05)$ difference in knowledge level of FFS farmers and non-FFS farmers.

\section{BIOETHICS AND BIOSSECURITY COMMITTEE APPROVAL}

We authors of the article entitled "Impact of farmer field school's training on knowledge level of citrus growers regarding improved production practices" declared, for all due purposes, that the project that gave rise to the present data has not been submitted for evaluation to the Ethics Committee of the "University College of Agriculture, University of Sargodha, Pakistan", but we are aware of the contents of Resolution No. 466, of December 12, 2012 of the Brazilian National Health Council $<$ http://conselho.saude.gov.br/resolucoes/2012/Reso466.pdf> because it involves human.
Thus, the authors assume full responsibility for the presented data and are available for possible questions, should they be required by the competent authorities.

\section{ACKNOWLEDGEMENTS}

The authors highly acknowledged the technical and financial support from Agricultural Information Institute (AII), Chinese Academy of Agricultural Sciences, Beijing, China.

\section{REFERENCES}

BALOCH, M.S. et al. Understanding perceptions regarding availability, quality, status and methods used in storing fruits and vegetables in Pakistan's Dera Ismail Khan District. JARQ, v.40, n.2, p.163-170, 2006. Available from: <http://www.jircas.affrc.go.jp>. Accessed: Aug. 09, 2016.

BUTT, T.M. et al. An Analysis of the Effectiveness Farmer Field School (FFS) Approach in Sustainable Rural Livelihood (SRL): The Experience of Punjab-Pakistan. Agricultural Sciences, v. 6, p. 1164-1175, 2015. Available from: <http://www.scirp.org/Journal/ PaperInformation.aspx?paperID=60365\&>. Accessed: Aug. 09, 2016.

ALI, S. et al. Role of private extension system in agricultural development through advisory services in the Punjab, Pakistan. Pakistan Journal of Science, v. 63, n. 02, p. 70-73, 2011. Available from: <http://www.paas.com.pk>. Accessed: Aug. 09, 2016.

GOVERNMENT OF PAKISTAN. Economic survey of Pakistan. Pakistan: Economic Advisor's Wing, Statistical Division, Islamabad, 2016. p. 342.

GOVERNMENT OF PAKISTAN. Fruit, vegetables and condiments statistics of Pakistan. Islamabad: Ministry of Food, Agriculture and Livestock, Economic Wing, 2016. p. 55.

IRSHAD, M.Q. et al. Impact of the IPM-FFS program on agronomic practices adopted by cotton growers in the Punjab, Pakistan. Journal of Agricultural Research, v. 54, n. 02, p. 321330, 2016. Available from: <http://apply.jar.punjab.gov.pk/issues/ current_issues/122>. Accessed: Aug. 09, 2016.

LUQMAN, M. et al. Impact of administrative changes on the working efficiency of extension field staff after decentralization in the Punjab, Pakistan. Journal of Agriculture \& Social Sciences, v. 01, n. 03, p. 223-226, 2005. Available from: < http://www.fspublishers.org/JASS. php>. Accessed: Aug. 09, 2016.

LANJOUW, J.O.; LANJOUW, P. The rural non-farm sector: issues and evidence from developing countries. Agricultural Economics Review, v.261, n.1, p.1-23, 2001. Available from: <http://www. eng.auth.gr/mattas/eng.htm>. Accessed: Aug. 09, 2016.

LODHI, T.E. et. al. Perceived effectiveness of public sector extension under decentralized agricultural extension system in the Punjab, Pakistan. Journal of Agriculture \& Social Sciences, v. 02, n. 03, p. 195-200, 2006. Available from: <http://www.fspublishers. org/JASS.php>. Accessed: Aug. 09, 2016.

MANCINI, F. et al. Increasing the environmental and social sustainability of cotton farming through farmer education in Andhra Pradesh, India. Agricultural Systems, v. 96, n.1-3, p.1625, 2008. Available from: <https://www.journals.elsevier.com/ agricultural-systems $>$. Accessed: Aug. 09, 2016. 
MUHAMMD, S.A. et al. Assessment of FFS approach through adult education: a special case of learning group of farming community (LGFS) in Punjab, Pakistan. International Journal of Agriculture \& Applied Sciences, v. 7, n. 2, p.177-181, 2015. Available from: $<$ https://www.uos.edu.pk/journals/ijaas>. Accessed: Aug. 09, 2016.

NMADU, J.N. et al. Socio-economic factors affecting adoption of innovations by Coca farmers in Ondo State, Nigeria. European Journal of Business, Economics and Accountancy, v. 3, n. 2, p.58-66, 2015. Available from: <http://www.idpublications.org/european-journal-ofbusiness-economics-and-accountancy/>. Accessed: Aug. 09, 2016.

PERKINS-VEAZIE, P.; COLLINS, J.K. Contribution of nonvolatile phytochemicals to nutrition and flavor. HortTechnology, v.11, p. 539-546, 2001. Available from: <http://horttech.ashspublications. org>. Accessed: Aug. 09, 2016.

BENTLEY, J. et. al. Comparing farmer field schools, community workshops and radio: Teaching Bolivian farmers about Bacterial
Wilt of Potato. Journal of International Agricultural and Extension Education, v. 14, n. 03, p. 45-61, 2007. Available from: $<$ http://www.aiaee.org/journal.html>. Accessed: Aug. 09, 2016.

TRIPP, R. et al. What should we expect from farmer field schools? A Sri Lanka case study. World Development, v. 33, n. 10, p. 1705-1720, 2005. Available from: <http://www.sciencedirect.com/ science/article/pii/S0305750X05001300>. Accessed: Aug. 09, 2016.

Van den Berg, H.; Jiggins, J. Investing in Farmers - The Impacts of Farmer Field Schools in Relation to Integrated Pest Management. World Development, v. 35, n. 04, p. 663-686, 2007. Available from: $<$ http://www.sciencedirect.com/science/>. Accessed: Aug. 09, 2016.

WINARTO, Y.T. State intervention and farmer creativity integrated pest management among rice farmers in Subang, West Java. Agriculture and Human Values, v.12, n.4, p.47-57, 2004. Available from: <https://ideas.repec.org/a/spr/agrhuv/v12y1995i4p47-57.html>. Accessed: Aug. 09, 2016. 